\title{
Imposex in Endemic Volutid from Northeast Brazil (Mollusca: Gastropoda)
}

\author{
Ítalo Braga de Castro $^{1 *}$, Carlos Augusto Oliveira de Meirelles ${ }^{2,3}$, Helena Matthews- \\ Cascon $^{2,3}$; Cristina de Almeida Rocha-Barreira ${ }^{2}$, Pablo Penchaszadeh ${ }^{4}$ and Gregório \\ Bigatti $^{5}$ \\ ${ }^{1}$ Laboratório de Microcontaminantes Orgânicos e Ecotoxicologia Aquática; Fundação Universidade Federal do \\ Rio Grande; C. P.: 474; italo_braga@yahoo.com.br; 96201-900; Rio Grande - RS -Brasil. ${ }^{2}$ Laboratório de \\ Zoobentos; Instituto de Ciências do Mar; Fortaleza - Ceará - Brasil. ${ }^{3}$ Laboratório de Invertebrados Marinhos; \\ Departamento de Biologia; Universidade Federal do Ceará; Fortaleza - CE - Brasil. ${ }^{4}$ Universidade de Buenos \\ Aires; Buenos Aires - Argentina. ${ }^{5}$ Centro Nacional Patagónico, Puerto Madryn - Chubut - Argentina
}

\begin{abstract}
Imposex is characterized by the development of masculine sexual organs in neogastropod females. Almost 120 mollusk species are known to present imposex when exposed to organic tin compounds as tributyltin (TBT) and triphenyltin (TPT). These compounds are used as biocide agents in antifouling paints to prevent the incrustations on boats. Five gastropod species are known to present imposex in Brazil: Stramonita haemastoma, Stramonita rustica, Leucozonia nassa, Cymathium parthenopeum and Olivancillaria vesica. This paper reports the first record of imposex observed in the endemic gastropod Voluta ebraea from Pacheco Beach, Northeast Brazil. Animals presenting imposex had regular female reproductive organs (capsule gland, oviduct and sperm-ingesting gland) and an abnormal penis. As imposex occurs in mollusks exposed to organotin compounds typically found at harbors, marinas, shipyards and areas with high shipping activities, probably contamination of Pacheco Beach is a consequence of a shipyard activity located in the nearest areas.
\end{abstract}

Key-words: Imposex, Voluta ebraea, Endemic, Brazil, Organotin, Contamination

\section{INTRODUCTION}

Imposex in gastropod mollusks has been widely used to monitor the contamination by organotin compounds all around the world (Morcillo and Porte, 1998; Axiak et al., 2002; Minchin, 2003). The reliability of this bioindicator is derived from the fact that imposex originates in one highly specific hormonal alteration, occurring just in gastropods exposed to organotin compounds (Matthiessen and Gibbs, 1998). More than a hundred gastropod species exhibited this response in a worldwide scale (Fioroni et al, 1991; Gibson and Wilson, 2003). Although imposex has already been observed in some studies in Latin America (Gooding et al., 1999; Penchaszadeh et al., 2001; Bigatti and Penchaszadeh, 2005; Cledòn et al, 2006), no monitoring studies over large areas have been carried out in this region.

In Central Chile, Osorio and Huaquín (2003) found symptoms of populational decline within populations of the muricid Acanthina monodon,

\footnotetext{
* Author for correspondence
} 
found in the proximity of port terminals. In Brazil, imposex was observed in the muricids Stramonita haemastoma (Castro et al., 2000; Fernandez et al., 2002; Fernandez et al., 2005), Stramonita rustica (Camillo et al., 2004; Castro et al., 2004), and in the olivid Olivancillaria vesica (Caetano and Absalão, 2003).

Voluta ebraea (Fig. 1A) is an endemic species from Northeast Brazil, occurring along the coast of Maranhão, Ceará, Rio Grande do Norte and Alagoas States (Matthews, 1969; Weaver and du Pont, 1970).

This study was aimed to verify the occurrence of imposex in volutid Voluta ebraea from Ceará State coast, Northeast Brazil.

\section{MATERIALS AND METHODS}

Adult specimens of $V$. ebraea were examined: three animals from Pacheco Beach, Caucaia County and eight animals from Icapuí County, in Ceará State coast (Fig. 1B).

Their shells were measured from the tip of the spiral to the siphonal canal using vernier caliper. The shell of each organism was then removed in order to examine the soft parts. Sexual identification was performed based on the presence of a capsule gland, oviducts and seminal receptacle in the females, and a prostate gland in the males. Animals with penis and capsule gland, oviducts and sperm-ingesting gland were considered imposexed females.
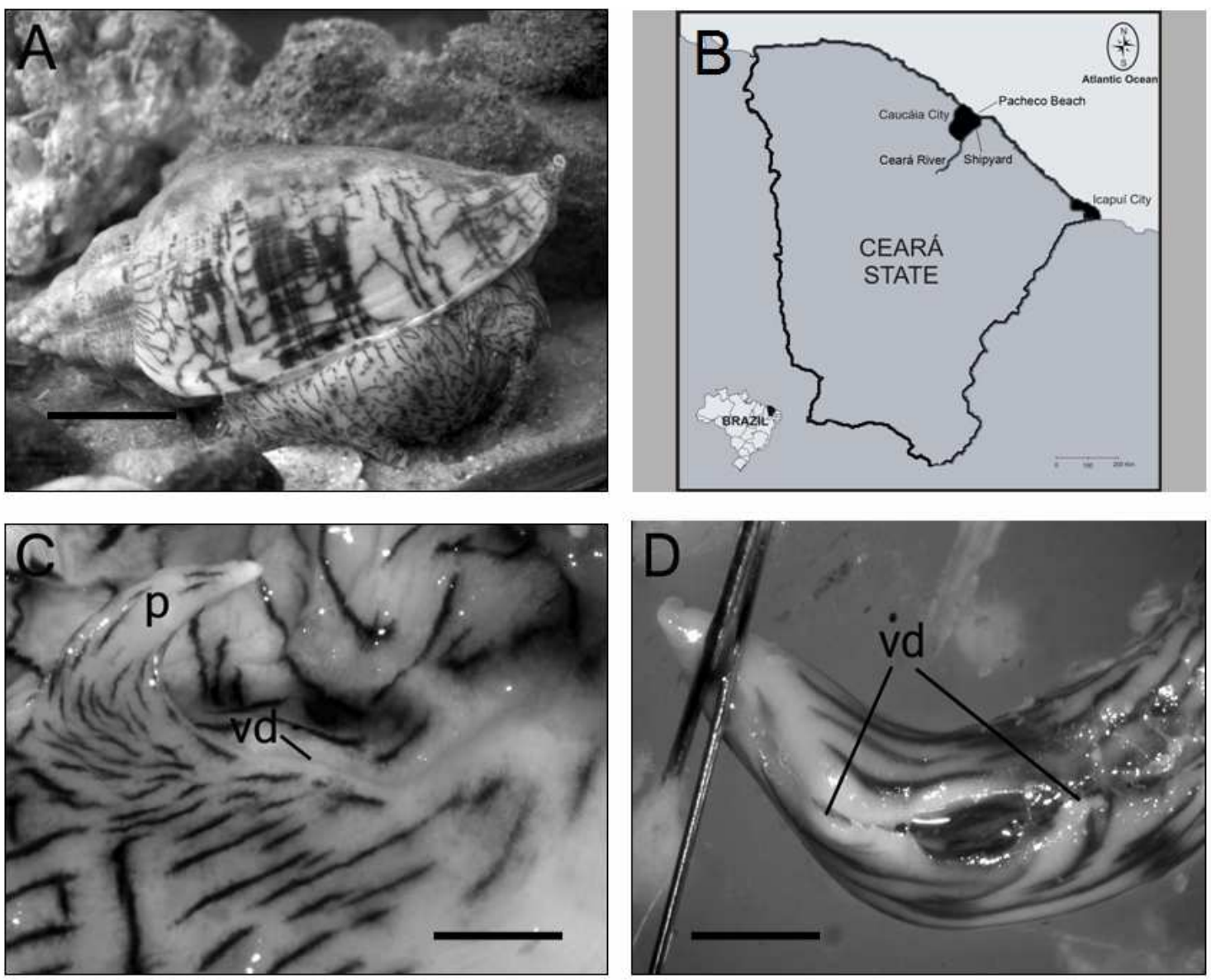

Figure 1 - Voluta ebraea. A. Adult individual from Northeast Brazil. B. Study areas at Ceará State, Northeast Brazil. C. Penis and vas deferens of an imposexed female from Pacheco Beach, Northeast Brazil. D. Detail of penis and vas deferens of a male from Pacheco Beach, Northeast Brazil. Abbreviations: p, penis; vd, vas deferens. Scale bars: $\mathbf{A}=2.6 \mathrm{~cm} ; \mathbf{C}=4 \mathrm{~mm} ; \mathbf{D}=0.5 \mathrm{~mm}$. 
Penis lengths were measured to the nearest millimeter. Imposex quantification was usually made by an index initially developed for the neogastropod Nucella lapillus (Gibbs and Bryan, 1987; Gibbs et al., 1987) and successfully used for others neogastropods (Minchin et al., 1996; Gooding et al., 1999).

The Relative Penis Length Index (RPLI = (Mean length of female penis) / (Mean length of male penis) $X$ 100). Was also investigated the relation between penis size and shell size in the collected animals.

\section{RESULTS}

Eleven adult animals were collected: 4 males and 7 females. 2 females from Pacheco Beach presented imposex. Other females from Icapuí County didn't show any evidence of this abnormality.

Imposex in Voluta ebraea was characterized by the development of a small conical penis (8.8 and $8.1 \mathrm{~mm}$ in length) and the presence of a guttershaped vas deferens, like an opened channel, as seen in the males of Volutinae (Fretter and Graham, 1994) (Figs. 1C and 1D). This channel was long, passing from the bottom of palial cavity to the penis tip.

RPLI index for $V$. ebraea from Pacheco Beach was 31.2 and males showed a higher relationship between penis size/shell size than imposexed females ( 0.57 and 0.17 , respectively).

\section{DISCUSSION}

According to Maia (1998), the predominant maritime current direction of Ceará coast is from east to west and, a lot of water and sediment from Ceará River is carried by this current to Pacheco Beach. There is a shipyard near Ceará River's estuary which repairs and constructs the boats and small ships. It is known that shipyards, harbors, marinas and other places with high shipping activities are potential areas of contamination by organotin compounds from antifouling paints (Sekizawa et al., 2003; Sudaryanto et al., 2004). Probably, the imposex observed in $V$. ebraea females from Pacheco Beach was induced by the animals exposition to these organotin compounds that were brought from Ceará River the by maritime current.

Studies conducted by Castro et al, 2000 didn't show imposex in muricid Stramonita haemastoma at Pacheco Beach. This semblable contradiction come reflect two different situations: the species Voluta ebraea might present high natural sensibility for organotin compounds which induced imposex or, and probably, the species $S$. haemastoma was not exposed to contamination as $V$. ebraea because the first one usually live upon rocky sediment and the second one live upon sandy sediment. According to Stronkhorsta et al., (2003) and Wezel and Vlaardingen, (2004) organotin compounds have high affinity for sediments.

High levels of imposex could lead some gastropod populations with intracapsular development to extinction (Gibbs and Bryan, 1986). Imposex high levels cause a tissue proliferation which blocks the females' genital system. This situation usually causes sterilization and death due to the presence of aborted capsules in the capsule gland (Gibbs and Bryan, 1986, Gibson and Wilson, 2003). Reproductive failure was observed in populations of muricid Nucella lapillus which severely declined during the 80's in southern England (Gibbs e Bryan, 1986) due to imposex effects and intracapsular development (no larval migration from healthy populations)(Spence et al., 1990).

$V$. ebraea imposexed females showed penis and vas deferens with a high level of development and RPLI index of 31.2, reflecting high levels of contamination by organotin compounds of Pacheco Beach. High RPLI values had been observed in some populations of Nucella lapillus of England southeastern (Bryan et al, 1986) and of Nassarius reticulatus from Spain (Barreiro et al, 2001). In these populations, high sterility index were observed in imposexed females. Thus, it would be very important to verify the occurrence of sterility in V. ebraea populations from Pacheco beach.

$V$. ebraea has an intracapsular metamorphosis larval development type (Matthews-Cascon, personal comunication), i.e, there are no plancton larval stages. This development type does not allow larval migration from a population to another one. Then, if one of these populations becomes sterile due to imposex abnormality, the risk of extinction is very high. This is an extreme concern with a preservationist point of view, once 
V. ebraea is an endemic mollusk species from Northeast Brazil (Matthews, 1969).

\section{ACKNOWLEDGEMENTS}

We thank Inês Xavier Martins for her help in the field work and we would like to thank CAPES, CNPq and SECYT for their financial support.

\section{RESUMO}

O imposex caracteriza-se pelo surgimento de estruturas sexuais masculinas, em fêmeas de gastrópodes. Cerca de 120 espécies de moluscos que exibem o fenômeno quando expostas a contaminação por compostos orgânicos de estanho tais como o Tributilestanho (TBT) e o Trifenilestanho (TPT). Esses compostos são utilizados, sobretudo em embarcações, no intuito de evitar a bioincrustração que danifica as embarcações e eleva os custos das viagens marítimas. No Brasil se conhecem 5 espécies de moluscos gastrópodes que manifestam imposex, são elas: Stramonita haemastoma, Stramonita rustica, Leucozonia nassa, Cymathium parthenopeum e Olivancillaria vesica. No Nordeste, monitoramentos da contaminação por organoestânicos foram realizados utilizando o imposex em gastrópodes como biomarcador. O presente estudo tem por objetivo notificar a primeira ocorrência de imposex na espécie endêmica do Nordeste brasileiro, Voluta ebraea. De um total de 11 animais observados, duas fêmeas apresentaram imposex, provenientes da Praia do Pacheco no litoral do Ceará. Observou-se nesses indivíduos a presença de glândula de cápsulas, ovidutos e receptáculo seminal concomitantemente ao pênis o que caracteriza o imposex. Como o imposex só se manifesta em moluscos expostos a compostos organoestânicos tipicamente encontrados em portos, marinas, estaleiros e locais com grande fluxo de embarcações atribui-se a origem dessa contaminação provavelmente a um estaleiro localizado nas proximidades da área de coleta.

\section{REFERENCES}

Axiak,V., Micallef, D., Muscat, J., Vella, A., and Mintoff, B. (2003), Imposex as a biomonitoring tool for marine pollution by tributyltin: some further observations. Environ.Int., 28, 743-749.

Barreiro, R., Gonzalez, R., Quintela, M., and Ruiz, J. M. (2001), Imposex, organotin bioaccumulation and sterility of female Nassarius reticulatus in polluted areas of NW Spain. Mar.Ecol.Prog.Ser., 218, 203212.

Bigatti, G. and Penchaszadeh,P. E. (2005), Imposex in Odontocymbiola magellanica (Caenogastropoda: Volutidae) in Patagonia. Com.Soc.Malacol.Urug., 88, 371-375.

Bryan, G. M., Gibbs, P. E., Humerstone, L. G., and Burt, G. R. (1986), The decline of the gastropod Nucella lapillus around Southwest England: Evidence for tributyltin from antifuoling paints. J. Mar. Biol. Ass. U. K., 66, 611-640.

Caetano, C. H. S. and Absalão, R. S. (2002), Imposex in Olivancillaria vesica vesica (Gmelin) (Gastropoda, Olividae) from a Southeastern Brazilian sandy beach. Rev.Bras.Zool., 19, 215-218.

Camillo, E., Quadros, J., Castro, I. B., and Fernandez, M. A. S. (2004), Imposex in Thais rustica (Mollusca:Neogastropoda) (Lamarck, 1822) as an indicator of organotin compounds pollution at Maceió coast (Northeastern Brazil). Braz.j.oceanogr., 52, 101-105.

Castro, I. B., Matthews-Cascon, H., and Fernandez, M. A. S. (2000), Imposex em Thais haemastoma (Linnaeus, 1767) (Mollusca: Gastropoda) uma indicação da contaminação por organoestânicos na costa do município de Fortaleza. Arq.Cien.Mar., 33, 51-56.

Castro, I. B., Meirelles, C. A. O., Matthews-Cascon, H., and Fernandez, M. A. S. (2004), Thais (Stramonita) rustica (Lamarck, 1822) (Mollusca: Gastropoda: Thaididae), a potential bioindicator of contamination by organotin Northeast Brazil. Braz.j.oceanogr., 52, 135-139.

Cledon, M., Theobald, N., Gerwinski, W., and Penchaszadeh, P. E. (2006), Imposex and organotin compounds in marine gastropods and sediments from the Mar del Plata coast, Argentina. J. Mar. Biol. Ass. $U . K ., 86,751-755$.

Fernandez, M. A., Wagener, A. d. L. R., Limaverde, A. M., Scofield, A. L., Pinheiro, F. M., and Rodrigues, E. (2005), Imposex and surface sediment speciation: A combined approach to evaluate organotin contamination in Guanabara Bay, Rio de Janeiro, Brazil. Mar. Environ. Res., 59, 435-452.

Fernandez,M.A.S., Limaverde,A.C., Castro,I.B., Wagener A.L.R., and Almeida,A.C.O. (2002), Occurence of imposex in Thais haemastoma: possible evidence of environmental contamination derived 
from organotin compounds in Rio de Janeiro and Fortaleza, Brazil. Rep.Publ.Heal., 18,

Fioroni,P., Oehlmann,J., and Stroben,E. (1991), The Pseudohermaphroditism of Prosobranchs Morphological Aspects. Zool.Anz., 226, 1-26.

Fretter, V. and Graham, A. (1994). British Prosobranch Molluscs. The Ray Society, London. 820p.

Gibbs,P.E. and Bryan,G.W. (1986), Reproductive Failure in Populations of the Dog-Whelk, NucellaLapillus, Caused by Imposex Induced by Tributyltin from Antifouling Paints. J.Mar.Biol.Ass.U.K., 66, 767-and

Gibbs, P. E. and Bryan, G. M. (1987), TBT paints and demise of the dog-whelk Nucella lapillus (Gastropoda). J. Mar. Biol. Ass. U. K., 68, 14821487.

Gibbs, P. E., Bryan, G. M., Pascoe, P. L., and Burt, G. R. (1987), The use of dog-whelk Nucella lapillus, as na indicator of tributyltin (TBT) contamination. $J$. Mar. Biol. Ass. U. K., 67, 507-523.

Gibson, C. P. and Wilson, S. P. (2003), Imposex still evident in eastern Australia 10 years after tributyltin restrictions. Mar. Environ. Res., 55, 101-112.

Gooding, M., Gallardo, C., and LeBlanc, G. (1999), Imposex in Three Marine Gastropod Species in Chile and Potential Impact on Muriciculture. Mar. Pollut. Bull., 38, 1227-1231.

Maia, L. P. (1998) Procesos costeros y balance sedimentario a lo largo de Fortaleza (NE-Brasil): Implicaciones para una gestión adecuada de la zona litoral. PhD Thesis, Universitad de Barcelona, Barcelona, Espanha

Matthiessen, P. and Gibbs, P. E. (1998), Critical appraisal of the evidence for tributyltin-mediated endocrine disruption in mollusks. Environ. Toxicol. Chem., 17, 37-43.

Minchin, D., Stroben, E., Oehlmann, J., Bauer, B., Duggan, C. B., and Keatinge, M. (1996), Biological indicators used to map organotin contamination in Cork Harbour, Ireland. Mar. Pollut. Bull., 32, 188195.

Minchin, D. (2003), Monitoring of tributyl tin contamination in six marine inflets using biological indicators. Marine Environmental and Health Series, 6, 1-15.

Morcillo, Y. and Porte, C. (1998), Monitoring of organotin compounds and their effects in marine molluscs. Trends in Analytical Chemistry, 17, 109116.
Osório, C. and Huaquin, L. G. (2003), Alteración de la sexualidad de Acanthina monodon (Pallas, 1774) (Gastropoda: Muricidae) em la litoral de Chile central, inducida por compuestos organoestañosos. Cienc. Tecnol. Mar, 26, 97-107.

Penchaszadeh, P. E., Averbuj, A., and Cledon, M. (2001), Imposex in gastropods from Argentina (South-Western Atlantic). Mar. Pollut. Bull., 42, 790791.

Sekizawa, J., Suter, G., and Birnbaum, L. (2003), Integrated Human and Ecological Risk Assessment: A Case Study of Tributyltin and Triphenyltin Compounds. Human.Ecol.Risk Assess., 9, 325-342.

Spence, S. K., Hawkins, S. J., and Santos, R. S. (1990), The Mollusk Thais-Haemastoma - An Exhibitor of Imposex and Potential Biological Indicator of Tributyltin Pollution. Marine Ecology-Pubblicazioni Della Stazione Zoologica di Napoli I, 11, 147-156.

Stronkhorst, J., Ariese, F., van Hattum, B., Postma, J. F., de Kluijver, M., Den Besten,P.J., Bergman,M. J. N., Daan, R., Murk, A. J., and Vethaak, A. D. (2003), Environmental impact and recovery at two dumping sites for dredged material in the North Sea. Environ.Pollut., 124, 17-31.

Sudaryanto, A., Takahashi, S., Iwata, H., Tanabe, S., and Ismail, A. (2004), Contamination of butyltin compounds in Malaysian marine environments. Environ.Pollut., 130, 347-358.

Weaver, C. S. and du Pont, J. E. (1970). The Living Volutes. Delaware Museum of Natural History. Greenville. 375p.

Wezel, A. P. and Vlaardingen, P. (2004). Environmental risk limits for antifouling substances. Aquat. Toxicol., 66,.427 -444.
Received: August 07, 2006; Revised: November 20, 2007; Accepted: June 13, 2008. 